\section{Modulating Weight Loss and Regain through Exercise and Dietary Protein}

\author{
Chaise A. Murphy, Karsten Koehler*
}

CrossMark

\title{
ABSTRACT
}

Efficacious weight loss which reduces risk of mortality requires both significant initial weight loss and prevention of weight regain. Performing either aerobic or resistance exercise and elevating protein intake during caloric restriction (CR) preserves - and may increaselean mass (LM), leading to targeted loss of fat mass. To maximize the LM retention stimulus achieved by consuming high-protein diets, gross and acute dosage, distribution and source of protein should all be optimized. Maintenance of LM during weight loss may improve satiety during $\mathrm{CR}$ and aids in the prevention of weight regain by blunting the post-CR hyperphagic response which causes overcompensation of fat mass regain known as the fat overshoot phenomenon. Overall, the combination of exercise and high protein diet promotes efficacious weight loss through preservation of LM, which resists weight regain.

Abbreviations Used: Fat Mass (FM); Caloric Restriction (CR); Lean Mass (LM); Energy Expenditure (EE); Recommended Dietary Allowance (RDA); High-Intensity Interval Training (HIIT); Myofibrillar Protein Synthesis (MPS)

*Correspondence to: Karsten Koehler, Department of Nutrition and Health Sciences, University of NebraskaLincoln, 104J Ruth Leverton Hall Lincoln, NE 68583-0806

kkoehler3@unl.edu

Cite This Article: Murphy, C.A., Koehler, K. 2017. Modulating Weight Loss and Regain through Dietary Protein and Exercise. Diabesity 3(3): 13-17. D0I: 10.15562/ diabesity.2017.44

\section{INTRODUCTION}

A 2005 world census found one-third of adults qualified as overweight or obese, ${ }^{1}$ placing billions of people at an increased risk of mortality. ${ }^{2,3}$ Contributions of excess adipose tissue, reduced proportion of muscle mass and lower physical activity to all-cause mortality underlie this increased risk..$^{4-7}$ Thus, weight loss, specifically the loss of fat mass (FM), is desirable for many individuals. Both caloric restriction (CR) and exercise can induce weight loss, but a recent review on free-living weight loss studies revealed CR results in $12-44 \%$ lower weight loss than expected and exercise results in 55-64\% lower weight loss than expected. ${ }^{8}$ And while achieving significant weight loss can be difficult for some, more individuals struggle to prevent weight regain. On average, individuals who undergo weight loss maintain less than $30 \%$ of their initial weight loss 4-5 years afterwards. ${ }^{9}$ Understanding how CR and exercise can be implemented to minimize weight regain while still promoting efficacious weight loss needs to be established. Only by minimizing weight regain will individuals experience effective long-term weight loss, reduce mortality risk and efficiently combat the obesity epidemic.

\section{EXERCISE AND ELEVATED PROTEIN INTAKE PROTECT LEAN MASS DURING WEIGHT LOSS}

Targeted loss of FM preserves lean mass (LM), including bone and skeletal muscle. By maintaining $\mathrm{LM}$, which is more metabolically active than $\mathrm{FM},{ }^{10}$ it stands to reason the decline in energy expenditure (EE) associated with weight loss could be blunted, though this has not been explicitly studied. Additionally, preserving bone mass reduces risk of osteoporosis and fractures, ${ }^{11}$ while maintaining muscle mass improves quality of life, ${ }^{12}$ and decreases risk of mortality. ${ }^{4}$ Even under moderate CR (20\%), muscle protein breakdown was found to be $60 \%$ higher compared to energy balance, highlighting the uphill battle individuals face in preserving LM during CR. ${ }^{13}$

A recent review attributed $25 \%$ of weight loss to loss of LM in overweight individuals using CR alone to lose weight. ${ }^{14}$ That value has been criticized as an underestimate ${ }^{15}$ and alternative approximations of $33 \%$ for women and $40 \%$ for men have been proposed based on regression analysis. ${ }^{16}$ Regardless, it appears overweight individuals lose at least one-quarter of weight lost as LM during CR-weight loss. That number drops to $12 \%$ when a combination of exercise and CR is used and to $0 \%$ 
when exercise alone is used to lose weight, ${ }^{14}$ demonstrating the preservative power of exercise on LM (Figure 1). Compared to aerobic exercise, resistance training may be more effective at inducing body composition changes. ${ }^{17}$ While aerobic training has been shown to elevate basal muscle protein synthesis, whether the elevation following aerobic training is myofibrillar or mitochondrial in nature remains disputed. ${ }^{18}$ Nonetheless, both modalities compound the LM-retention stimulus, ${ }^{20,21}$ potentially increasing LM during CR-weight loss, ${ }^{22-24}$ and neither exercise modality produces initial weight loss above and beyond calorically equivalent CR. ${ }^{17,19}$ According to a small meta-analysis, adding either modality of exercise to CR preserved more lean mass and promoted the loss of greater amounts of fat mass. ${ }^{25}$ Thus, performing either aerobic or resistance exercise during CR appears to effectively target loss of FM.

During CR, elevating protein intake at the expense of carbohydrate or fat preserves lean mass. ${ }^{23,24,26-33}$ Achieving the RDA protein intake $(0.8 \mathrm{~g} / \mathrm{kg})$ in populations who consume $<0.8 \mathrm{~g} / \mathrm{kg}$ can help preserve LM. ${ }^{26}$ Intakes exceeding the RDA result in elevation of MPS to energy balance levels and further preservation of LM, though intakes exceeding $1.6 \mathrm{~g} / \mathrm{kg}$ appear to provide little additional benefit to the MPS stimulus. ${ }^{32}$ In one study, LM increased in participants who consumed $2.4 \mathrm{~g} / \mathrm{kg}$ protein while performing resistance exercise and high-intensity interval training (HIIT) under $40 \%$ $\mathrm{CR}$, whereas participants consuming $1.2 \mathrm{~g} / \mathrm{kg}$ only maintained $\mathrm{LM}^{22}$ suggesting a measurable dose-response above $1.2 \mathrm{~g} / \mathrm{kg}$. While it is unclear whether $2.4 \mathrm{~g} / \mathrm{kg}$ produces greater LM gains than $1.6 \mathrm{~g} / \mathrm{kg}$, the threshold for gross protein intake that

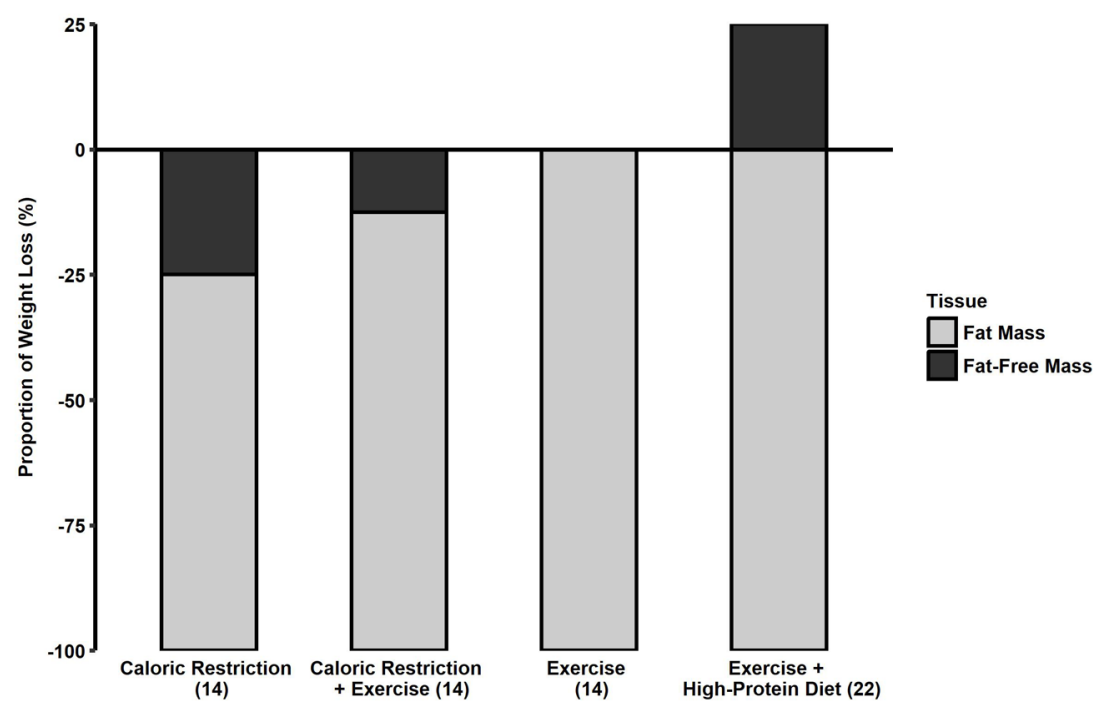

Figure 1 Contribution of Fat Mass and Fat-Free Mass to Weight Loss by Intervention maximally stimulates LM retention likely resides between 1.6 and $2.4 \mathrm{~g} / \mathrm{kg}$. Furthermore, combining protein intakes of $1.4-1.6 \mathrm{~g} / \mathrm{kg}$ with resistance exercise during CR exceeds MPS energy balance levels. ${ }^{34}$ Thus, maximizing LM retention during CR appears to require a combination of protein intake approximately twice the RDA and an exercise stimulus.

\section{Increased Protein Intakes Promote Weight Loss}

Conflicting evidence exists whether high protein diets promote greater weight loss than calorically-equivalent low protein diets. Given the ability of protein to produce a greater thermic effect of food than fat or carbohydrate, ${ }^{35}$ high protein diets promoting greater weight loss seems logical. In fact, replacing $17-18 \%$ of calories from carbohydrate with pork or soy protein was shown to elevate 24-hour EE. ${ }^{36}$ potentially signaling the significance of this cumulative thermic effect throughout a day. Additionally, over six months, greater fat and weight loss resulted from consuming $25 \%$ of calories as protein compared to $12 \%$ in one study. ${ }^{37}$ Greater retention of LM, the major determinant of resting EE, ${ }^{38}$ could also contribute to this effect. Finally, a series of studies investigating the carbohydrate to protein ratio of diets as a determinant of weight loss showed ratios (1.0-1.4) corresponding to $1.0-1.6 \mathrm{~g} / \mathrm{kg}$ protein produced more weight loss than ratios (3.0-3.5) corresponding to $0.7-0.8 \mathrm{~g} / \mathrm{kg}$ protein with ${ }^{20,21}$ or without ${ }^{39}$ exercise in short-term interventions. However, many studies failed to find significant differences in weight loss between low- and high-protein diets. ${ }^{28,29,32,40-42}$ One study, which examined blood lipid profiles of participants, reconciled the inability of the high-protein diet to produce more weight loss by showing that while individuals with healthy triglyceride levels lost equal amounts of weight on high- and low-protein diets, individuals with elevated triglyceride levels lost significantly less weight on a low-protein diet over a twelve-week intervention. ${ }^{43}$ Thus, the question of whether high protein diets can produce greater weight loss over short- and long-term durations remains relatively controversial, though the metabolic health of the individuals seeking to lose weight has been postulated to play a role.

\section{Protein Source and Distribution Influence Lean Mass Preservation}

Protein source and distribution present two confounding factors which may influence the longterm LM preservation response to high protein diet. Despite differences in their ability to acutely stimulate myofibrillar protein synthesis (MPS) in an energy balance state, ${ }^{44}$ soy, ${ }^{27}$ casein and whey ${ }^{24}$ 
have all been shown to preserve or increase LM during CR weight loss. However, casein supplementation produced twice the strength and LM gains of whey supplementation during 12-weeks of resistance training under $20 \%$ CR in one study ${ }^{24}$ suggesting slow-absorbing casein may be a superior protein source during CR weight loss for improving LM retention. Research showing casein consumption provides superior 7 hour leucine balance compared to whey protein supports this observation. ${ }^{45}$ Additionally, distributing protein intake evenly throughout the day has been shown to elevate MPS compared to skewed protein intake without an exercise stimulus. ${ }^{47}$ Protein distribution influences cumulative MPS throughout the day; consuming $20 \mathrm{~g}$ protein every 3 hours was shown to produce a larger cumulative MPS response than $40 \mathrm{~g}$ every 6 hours and $10 \mathrm{~g}$ every 1.5 hours following an acute bout of resistance exercise. ${ }^{46}$ Additional literature describes a plateau of acute MPS stimulation around 20g, ${ }^{48,49}$ suggesting $40 \mathrm{~g}$ every 3 hours may not be superior to $20 \mathrm{~g}$ every 3 hours. Forming a comprehensive dietary intervention taking into account the above recommendations on source, timing and dose of protein consumption will likely create the most beneficial LM retention stimulus during CR-weight loss.

\section{Preservation of Lean Mass Reduces the Risk of Weight Regain}

When consuming a high protein diet, participants tend to regain less weight than when consuming normal protein diets. ${ }^{50-52}$ One year after a 12-week weight loss program, participants consuming the most protein maintained the most weight loss despite nonsignificant group differences in initial weight loss. ${ }^{40}$ The ability to more effectively maintain weight loss on a high-protein diet may stem from the aforementioned preservation of LM. It appears the body engages in post-weight loss hyperphagia in order to restore pre-CR levels of LM. ${ }^{53}$ However, because FM is easier to gain than LM, this hyperphagic response often results in elevated FM above what was originally present. In one study, overweight individuals lost $72 \%$ of weight loss as FM, but $89 \%$ of weight regain resulted from gain of $\mathrm{FM},{ }^{54}$ a response coined the fat overshoot phenomenon. ${ }^{53}$ Thus, preservation of LM with a high-protein diet may potentially blunt the post-CR hyperphagic response.

The post-CR hyperphagic response may correlate with suboptimal protein intakes driving an increased desire to consume protein. Following two weeks of $0.5 \mathrm{~g} / \mathrm{kg}$ protein intake, individuals preferentially consumed higher amounts of ad libitum protein compared to individuals consuming $2.0 \mathrm{~g} / \mathrm{kg}$ protein, despite no differences in energy intake. ${ }^{55}$ With readily available high-protein options in this study, energy intake was not increased, but in a free-living environment without provided food, attempting to increase protein intake could result in a concurrent increase in energy intake. Additionally, participants in this study were not subjected to $\mathrm{CR}$, which may influence the postlow protein response; elevated muscle protein breakdown during CR may drive a greater need for protein and/or energy intake to achieve protein balance following CR. Further research is needed to investigate this hypothesis.

A substantial body of evidence suggests high-protein diet consumption during CR improves satiety. ${ }^{30,41,52,56,57}$ These effects have been shown both in acute and long-term studies. Following a 99\% carbohydrate lunch, participants consumed 31\% more calories at an ad libitum dinner than participants consuming a $71.5 \%$ protein lunch. ${ }^{58}$ In another study, participants consumed $18 \%$ fewer calories on a high protein diet over a six-month intervention, ${ }^{37}$ highlighting the longevity of protein's satiating effects. However, different sources of protein may provide different levels of acute physiological and subjective satiety ${ }^{59}$ and more research should evaluate the satiating effect of different protein sources under CR. Nonetheless, due to the large body of evidence supporting improved satiety and preservation of LM with high protein diet consumption, the ability of a high-protein diet to preserve LM and prevent weight regain may underscore the improvements in satiety. Substantial further research is needed to elucidate the potential connection between these two ubiquitous outcomes.

\section{CONCLUSION}

Consuming a high-protein diet during CR results in preservation of LM and improved satiety. While high-protein seem to promote lower weight regain, conflicting evidence exists whether high-protein diets can also result in greater initial weight loss. Based on available evidence, overweight or obese individuals seeking to lose weight and/or maintain weight loss should combine high protein intake (1.6 $\mathrm{g} / \mathrm{kg}$ or greater) with CR and either resistance or aerobic exercise to maximize the proportion of FM lost during weight loss. In conclusion, elevating protein intake during an energy deficit induced by $\mathrm{CR}$, exercise or a combination improves the likelihood of success in weight loss endeavours through retention of lean mass and improved satiety.

\section{WORKS CITED}

1. Kelly T, Yang W, Chen CS, Reynolds K, He J. Global burden of obesity in 2005 and projections to 2030. Int J Obes (Lond). 2008;32(9):1431-7. 
2. Adams KF, Schatzkin A, Harris TB, Kipnis V, Mouw T, Ballard-Barbash R, et al. Overweight, obesity, and mortality in a large prospective cohort of persons 50 to 71 years old. N Engl J Med. 2006;355(8):763-78.

3. Global BMI Mortality Collaboration, Di Angelantonio E, Bhupathiraju SN, Wormser D, Gao P, Kaptoge S, et al. Body-mass index and all-cause mortality: individual-participant-data meta-analysis of 239 prospective studies in four continents. Lancet. 2016;388(10046):776-86.

4. Wannamethee SG, Shaper AG, Lennon L, Whincup PH. Decreased muscle mass and increased central adiposity are independently related to mortality in older men. Am J Clin Nutr. 2007;86(5):1339-46.

5. Ekelund U, Ward HA, Norat T, Luan J, May AM, Weiderpass E, et al. Physical activity and all-cause mortality across levels of overall and abdominal adiposity in European men and women: the European Prospective Investigation into Cancer and Nutrition Study (EPIC). Am J Clin Nutr. 2015;101(3):613-21.

6. Hu FB, Willett WC, Li T, Stampfer MJ, Colditz GA, Manson JE. Adiposity as compared with physical activity in predicting mortality among women. N Engl J Med. 2004;351(26):2694-703.

7. Sui X, LaMonte MJ, Laditka JN, Hardin JW, Chase N, Hooker SP, et al. Cardiorespiratory fitness and adiposity as mortality predictors in older adults. JAMA. 2007;298(21):2507-16.

8. Dhurandhar EJ, Kaiser KA, Dawson JA, Alcorn AS, Keating KD, Allison DB. Predicting adult weight change in the real world: a systematic review and meta-analysis accounting for compensatory changes in energy intake or expenditure. Int J Obes (Lond). 2015;39(8):1181-7.

9. Anderson JW, Konz EC, Frederich RC, Wood CL. Longterm weight-loss maintenance: a meta-analysis of US studies. Am J Clin Nutr. 2001;74(5):579-84.

10. Muller MJ, Wang Z, Heymsfield SB, Schautz B, BosyWestphal A. Advances in the understanding of specific metabolic rates of major organs and tissues in humans. Curr Opin Clin Nutr Metab Care. 2013;16(5):501-8.

11. Siris ES, Miller PD, Barrett-Connor E, Faulkner KG, Wehren LE, Abbott TA, et al. Identification and fracture outcomes of undiagnosed low bone mineral density in postmenopausal women: results from the National Osteoporosis Risk Assessment. JAMA. 2001;286(22):2815-22.

12. Janssen I, Heymsfield SB, Ross R. Low relative skeletal muscle mass (sarcopenia) in older persons is associated with functional impairment and physical disability. J Am Geriatr Soc. 2002;50(5):889-96.

13. Carbone JW, Pasiakos SM, Vislocky LM, Anderson JM, Rodriguez NR. Effects of short-term energy deficit on muscle protein breakdown and intramuscular proteolysis in normal-weight young adults. Appl Physiol Nutr Metab. 2014;39(8):960-8.

14. Weinheimer EM, Sands LP, Campbell WW. A systematic review of the separate and combined effects of energy restriction and exercise on fat-free mass in middle-aged and older adults: implications for sarcopenic obesity. Nutr Rev. 2010;68(7):375-88.

15. Heymsfield SB, Gonzalez MC, Shen W, Redman L, Thomas D. Weight loss composition is one-fourth fat-free mass: a critical review and critique of this widely cited rule. Obes Rev. 2014;15(4):310-21.

16. Dixon JB, Lambert EA, Grima M, Rice T, Lambert GW, Straznicky NE. Fat-free mass loss generated with weight loss in overweight and obese adults: What may we expect? Diabetes Obes Metab. 2015;17(1):91-3.

17. Clark JE. Erratum to: Diet, exercise or diet with exercise: comparing the effectiveness of treatment options for weight-loss and changes in fitness for adults (18-65 years old) who are overfat, or obese; systematic review and meta-analysis. J Diabetes Metab Disord. 2015;14:73.

18. Burd NA, Tang JE, Moore DR, Phillips SM. Exercise training and protein metabolism: influences of contraction, protein intake, and sex-based differences. J Appl Physiol (1985). 2009;106(5):1692-701.
19. Nicklas BJ, Wang X, You T, Lyles MF, Demons J, Easter L, et al. Effect of exercise intensity on abdominal fat loss during calorie restriction in overweight and obese postmenopausal women: a randomized, controlled trial. Am J Clin Nutr. 2009;89(4):1043-52.

20. Layman DK, Evans E, Baum JI, Seyler J, Erickson DJ, Boileau RA. Dietary protein and exercise have additive effects on body composition during weight loss in adult women. J Nutr. 2005;135(8):1903-10.

21. Meckling KA, Sherfey R. A randomized trial of a hypocaloric high-protein diet, with and without exercise, on weight loss, fitness, and markers of the Metabolic Syndrome in overweight and obese women. Appl Physiol Nutr Metab. 2007;32(4):743-52.

22. Longland TM, Oikawa SY, Mitchell CJ, Devries MC, Phillips SM. Higher compared with lower dietary protein during an energy deficit combined with intense exercise promotes greater lean mass gain and fat mass loss: a randomized trial. Am J Clin Nutr. 2016;103(3):738-46.

23. Josse AR, Atkinson SA, Tarnopolsky MA, Phillips SM. Increased consumption of dairy foods and protein during diet- and exercise-induced weight loss promotes fat mass loss and lean mass gain in overweight and obese premenopausal women. J Nutr. 2011;141(9):1626-34.

24. Demling RH, DeSanti L. Effect of a hypocaloric diet, increased protein intake and resistance training on lean mass gains and fat mass loss in overweight police officers. Ann Nutr Metab. 2000;44(1):21-9.

25. Miller CT, Fraser SF, Levinger I, Straznicky NE, Dixon JB, Reynolds J, et al. The effects of exercise training in addition to energy restriction on functional capacities and body composition in obese adults during weight loss: a systematic review. PLoS One. 2013;8(11):e81692.

26. Bopp MJ, Houston DK, Lenchik L, Easter L, Kritchevsky SB, Nicklas BJ. Lean mass loss is associated with low protein intake during dietary-induced weight loss in postmenopausal women. J Am Diet Assoc. 2008;108(7):1216-20.

27. Deibert P, König D, Schmidt-Trucksaess A, Zaenker KS, Frey I, Landmann U, et al. Weight loss without losing muscle mass in pre-obese and obese subjects induced by a high-soy-protein diet. Int J Obes Relat Metab Disord. 2004;28(10):1349-52.

28. Farnsworth E, Luscombe ND, Noakes M, Wittert G, Argyiou E, Clifton PM. Effect of a high-protein, energy-restricted diet on body composition, glycemic control, and lipid concentrations in overweight and obese hyperinsulinemic men and women. Am J Clin Nutr. 2003;78(1):31-9.

29. Frestedt JL, Zenk JL, Kuskowski MA, Ward LS, Bastian ED. A whey-protein supplement increases fat loss and spares lean muscle in obese subjects: a randomized human clinical study. Nutr Metab (Lond). 2008;5:8.

30. Leidy HJ, Carnell NS, Mattes RD, Campbell WW. Higher protein intake preserves lean mass and satiety with weight loss in pre-obese and obese women. Obesity (Silver Spring). 2007;15(2):421-9.

31. Mettler S, Mitchell N, Tipton KD. Increased protein intake reduces lean body mass loss during weight loss in athletes. Med Sci Sports Exerc. 2010;42(2):326-37.

32. Pasiakos SM, Cao JJ, Margolis LM, Sauter ER, Whigham LD, McClung JP, et al. Effects of high-protein diets on fat-free mass and muscle protein synthesis following weight loss: a randomized controlled trial. Faseb J. 2013;27(9):3837-47.

33. Krieger JW, Sitren HS, Daniels MJ, Langkamp-Henken B. Effects of variation in protein and carbohydrate intake on body mass and composition during energy restriction: a meta-regression 1. Am J Clin Nutr. 2006;83(2):260-74.

34. Areta JL, Burke LM, Camera DM, West DW, Crawshay S, Moore DR, et al. Reduced resting skeletal muscle protein synthesis is rescued by resistance exercise and protein ingestion following short-term energy deficit. Am J Physiol Endocrinol Metab. 2014;306(8):E989-97.

35. Raben A, Agerholm-Larsen L, Flint A, Holst JJ, Astrup A. Meals with similar energy densities but rich in protein, fat, carbohydrate, or alcohol have different effects on energy 
expenditure and substrate metabolism but not on appetite and energy intake. Am J Clin Nutr. 2003;77(1):91-100.

36. Mikkelsen PB, Toubro S, Astrup A. Effect of fat-reduced diets on 24-h energy expenditure: comparisons between animal protein, vegetable protein, and carbohydrate. Am J Clin Nutr. 2000;72(5):1135-41.

37. Skov AR, Toubro S, Rønn B, Holm L, Astrup A. Randomized trial on protein vs carbohydrate in ad libitum fat reduced diet for the treatment of obesity. Int J Obes Relat Metab Disord. 1999;23(5):528-36.

38. Nelson KM, Weinsier RL, Long CL, Schutz Y. Prediction of resting energy expenditure from fat-free mass and fat mass. Am J Clin Nutr. 1992;56(5):848-56.

39. Layman DK, Boileau RA, Erickson DJ, Painter JE, Shiue H, Sather C, et al. A reduced ratio of dietary carbohydrate to protein improves body composition and blood lipid profiles during weight loss in adult women. J Nutr. 2003;133(2):411-7.

40. Clifton PM, Keogh JB, Noakes M. Long-term effects of a high-protein weight-loss diet. Am J Clin Nutr. 2008;87(1):23-9.

41. Johnston CS, Tjonn SL, Swan PD. High-protein, low-fat diets are effective for weight loss and favorably alter biomarkers in healthy adults. J Nutr. 2004;134(3):586-91.

42. Sacks FM, Bray GA, Carey VJ, Smith SR, Ryan DH, Anton SD, et al. Comparison of weight-loss diets with different compositions of fat, protein, and carbohydrates. N Engl J Med. 2009;360(9):859-73.

43. Noakes M, Keogh JB, Foster PR, Clifton PM. Effect of an energy-restricted, high-protein, low-fat diet relative to a conventional high-carbohydrate, low-fat diet on weight loss, body composition, nutritional status, and markers of cardiovascular health in obese women. Am J Clin Nutr. 2005;81(6):1298-306.

44. Tang JE, Moore DR, Kujbida GW, Tarnopolsky MA, Phillips SM. Ingestion of whey hydrolysate, casein, or soy protein isolate: effects on mixed muscle protein synthesis at rest and following resistance exercise in young men. J Appl Physiol (1985). 2009;107(3):987-92.

45. Boirie Y, Dangin M, Gachon P, Vasson MP, Maubois JL, Beaufrère B. Slow and fast dietary proteins differently modulate postprandial protein accretion. Proc Natl Acad Sci U S A. 1997;94(26):14930-5.

46. Areta JL, Burke LM, Ross ML, Camera DM, West DW, Broad EM, et al. Timing and distribution of protein ingestion during prolonged recovery from resistance exercise alters myofibrillar protein synthesis. J Physiol. 2013;591(9):2319-31.

47. Mamerow MM, Mettler JA, English KL, Casperson SL, Arentson-Lantz E, Sheffield-Moore M, et al. Dietary protein distribution positively influences 24 -h muscle protein synthesis in healthy adults. J Nutr. 2014;144(6):876-80.

48. Moore DR, Robinson MJ, Fry JL, Tang JE, Glover EI, Wilkinson SB, et al. Ingested protein dose response of muscle and albumin protein synthesis after resistance exercise in young men. Am J Clin Nutr. 2009;89(1):161-8.
49. Witard OC, Jackman SR, Breen L, Smith K, Selby A, Tipton KD. Myofibrillar muscle protein synthesis rates subsequent to a meal in response to increasing doses of whey protein at rest and after resistance exercise. Am J Clin Nutr. 2014;99(1):86-95.

50. Arciero PJ, Edmonds R, He F, Ward E, Gumpricht E, Mohr A, et al. Protein-Pacing Caloric-Restriction Enhances Body Composition Similarly in Obese Men and Women during Weight Loss and Sustains Efficacy during Long-Term Weight Maintenance. Nutrients. 2016;8(8).

51. Santarpia L, Contaldo F, Pasanisi F. Body composition changes after weight-loss interventions for overweight and obesity. Clin Nutr. 2013;32(2):157-61.

52. Westerterp-Plantenga MS, Lejeune MP, Nijs I, van Ooijen M, Kovacs EM. High protein intake sustains weight maintenance after body weight loss in humans. Int J Obes Relat Metab Disord. 2004;28(1):57-64.

53. Dulloo AG, Jacquet J, Girardier L. Autoregulation of body composition during weight recovery in human: the Minnesota Experiment revisited. Int J Obes Relat Metab Disord. 1996;20(5):393-405.

54. Pourhassan M, Bosy-Westphal A, Schautz B, Braun W, Glüer CC, Müller MJ. Impact of body composition during weight change on resting energy expenditure and homeostasis model assessment index in overweight nonsmoking adults. Am J Clin Nutr. 2014;99(4):779-91.

55. Griffioen-Roose S, Mars M, Siebelink E, Finlayson G, Tomé D, de Graaf C. Protein status elicits compensatory changes in food intake and food preferences. Am J Clin Nutr. 2012;95(1):32-8.

56. Martens EA, Lemmens SG, Westerterp-Plantenga MS. Protein leverage affects energy intake of high-protein diets in humans. Am J Clin Nutr. 2013;97(1):86-93.

57. Weigle DS, Breen PA, Matthys CC, Callahan HS, Meeuws KE, Burden VR, et al. A high-protein diet induces sustained reductions in appetite, ad libitum caloric intake, and body weight despite compensatory changes in diurnal plasma leptin and ghrelin concentrations. Am J Clin Nutr. 2005;82(1):41-8.

58. Latner JD, Schwartz M. The effects of a high-carbohydrate, high-protein or balanced lunch upon later food intake and hunger ratings. Appetite. 1999;33(1):119-28.

59. Hall WL, Millward DJ, Long SJ, Morgan LM. Casein and whey exert different effects on plasma amino acid profiles, gastrointestinal hormone secretion and appetite. Br J Nutr. 2003;89(2):239-48.

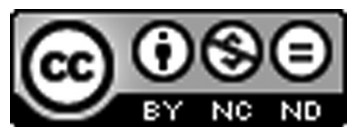

This work is licensed under a Creative Commons Attribution-Non Commercial-No Derivatives 4.0 International License. To view a copy of this license, visit http://creativecommons.org/licenses/by-nc-nd/4.0/ 